\title{
Implementation of Tempo in Rhythmic Music Learning in a Pandemic Period for Junior High School Students
}

\author{
Faraz Hilmi Heidar', Rina Maryanti ${ }^{2, *}$, Verra Wulandary ${ }^{3}$, Asep Rudi Irawan ${ }^{4}$ \\ ${ }^{1}$ Departemen Pendidikan Seni Musik, Universitas Pendidikan Indonesia, Indonesia \\ ${ }^{2}$ Departemen Pendidikan Kimia, Universitas Pendidikan Indonesia, Indonesia \\ ${ }^{3}$ Graduate School of International Development and Cooperation, Hirosima University, Japan \\ ${ }^{4}$ School of Human Sciences, University of Tsukuba, Japan \\ *Corresponding author : maryanti.rina@upi.edu
}

\begin{abstract}
Abstrak: Sistem pembelajaran dalam kegiatan belajar mengajar di masa pandemi ini memberikan tantangan tersendiri bagi guru dalam menyampaikan materi pembelajaran agar tersampaikan dengan baik kepada siswa. Tujuan dari penelitian ini adalah untuk memaksimalkan dan menyelenggarakan pembelajaran musik ritmis di masa pandemi Covid19. Untuk mendukung penelitian tersebut, kami melakukan metode penelitian deskriptif kuantitatif. Penelitian dilakukan di Sekolah Menengah Pertama. Dengan metode pemberian pretest-posttest. Teknik pengumpulan data yang digunakan adalah melalui Google Form. Materi yang diberikan berupa video tentang musik berirama, yang kemudian siswa dituntut untuk memahami secara teknis sesuai dengan yang telah diajarkan dalam video tersebut. Penelitian ini dilakukan sebelum dan sesudah pemberian materi untuk mengetahui tingkat pemahaman siswa terhadap materi. Dari data yang diperoleh dari hasil Google Form menunjukkan sebanyak 31.5\% siswa dapat mengolah tempo dengan baik, dan dapat dilihat pula seberapa jauh tingkat pemahaman siswa terhadap materi yang telah diajarkan, kita dapat menemukan beberapa kemampuan siswa dalam mengolah tempo melalui ritmik sehingga dapat dipraktikkan ke dalam alat musik.
\end{abstract}

Kata Kunci: Implementasi, Musik, Pembelajaran, Pendidikan, Ritmik, Tempo

\begin{abstract}
The learning system in teaching and learning activities during this pandemic provides its own challenges for teachers in delivering learning materials so that they are conveyed well to students. The purpose of this research is to maximize and organize rhythmic music learning during the Covid-19 pandemic. To support this research, we conducted a quantitative descriptive research method. The research was conducted in Junior High School. With the method of giving pretest-posttest. The data collection technique used is through Google Form. The material provided is in the form of a video about rhythmic music, which students are then required to understand technically according to what has been taught in the video. This research was conducted before and after giving the material to determine the level of students' understanding of the material. From the data obtained from the Google Form results, it shows that as many as $31.5 \%$ of students can process the tempo well, and it can also be seen how far the level of students' understanding of the material that has been taught, we can find some of the students' abilities in processing tempo through rhythmic so that it can be practiced in the musical instrument.
\end{abstract}

Keywords: Education, Implementation, Learning, Music, Rhithmic, Tempo

Volume 3, Nomor 1, Maret 2022 | 53

Implementation of Tempo in Rhythmic Music Learning in a Pandemic Period for Junior High School Students Faraz Hilmi Heidar, Rina Maryanti, Verra Wulandary, Asep Rudi Irawan

https://doi.org/10.26874/jakw.v3i1.142 


\section{Introduction}

Education is actually a place where teaching and learning activities occur to develop the potential of students. The purpose of education itself is to develop capabilities and shape the character and civilization of a dignified nation in order to educate the nation's life. Quality education cannot be separated from the role of a teacher. Teachers have an important role in the formation of a well-organized education system in order to create optimal education (Syafi' $i$ et al., 2018). Education during the pandemic is forced to be done online. Learning media is a teaching and learning process and serves to clarify the meaning of the message conveyed so that it can achieve learning objectives better and more perfectly (Fajra et al.,2020). One of the functions of learning media is as a teaching aid that also influences the climate, conditions, and learning environment that are arranged and created by the teacher. That is, learning media are teaching aids that are very important in the teaching and learning process in the learning environment in learning (Fajra et al., 2020). Online learning makes teaching and learning activities accessible from various times and places (Shukla et al., 2020). The use of online media also allows students to get wider information through the internet (Hastini et al., 2020). Through interesting learning media and according to students' needs can increase student learning motivation because students' attention to lessons can increase, provide a comprehensive experience in learning so that students can understand in real terms the material provided better understand the material as a whole, students are involved in the learning process so that students actively following and involved in the learning process and students have the opportunity to be creative and develop their potential (Nurita et al., 2018). The Minister of Education and Culture hopes that with the implementation of online or distance learning, students will also gain new experiences in the learning process.

Music education is a cultural product in which it represents cultural values. Facing technological advances, the paradigm of music education must be able to adapt to existing social conditions (Audina \& Kosasih, 2018; Hidayatullah, 2020). In learning arts and culture, especially music, teachers need practice in providing material that can encourage students to solve problems on how to deliver practical material online. This learning model helps the teaching and learning process that is carried out even though it is distanced so as to reduce obstacles that may occur in the real world. However, previous research on tempo and rhythmic in music did not discuss how the efficiency and response of students to the application of notation in music learning. Therefore, further research was conducted to determine how the 
efficiency and response of students to the application of rhythmic tempo in the music learning process.

\section{Methods}

The research was conducted in Junior High School in Bandung, Indonesia. With the method of giving pretest-posttest. The data collection technique used is through Google Form for learning media. Learning media is important in improving the learning process (Ferdiyansyah et al., 2020). Therefore, the use of media can improve learning outcomes. This argument is strengthened by the assumption that the use of media aims to make students more active, effective, and interactive. This research was conducted before and after giving the material to determine the level of students' understanding of the material being taught. From the data obtained from the results of the Google Form will show the results of certain student evaluations.

\section{Results and Discussion}

This study uses a survey method to several junior high school students through a google form which is filled in by some of the students both before giving the material (pre-test), and after being given the material (post-test) and then practicing it. The material is in the form of a video material from the Youtube platform link listed on the google form, and students practice by imitating it according to the material that has been given, and then evaluated by the teacher. The number of uses of online learning media can not be separated from the many features provided in the application (Zhafira et al., 2020).

The material provided is in the form of a video shown in Figure 1 and Figure 2. The result of the pretest that describe the initial conditions of students before being given the material are shown in Table 1. 


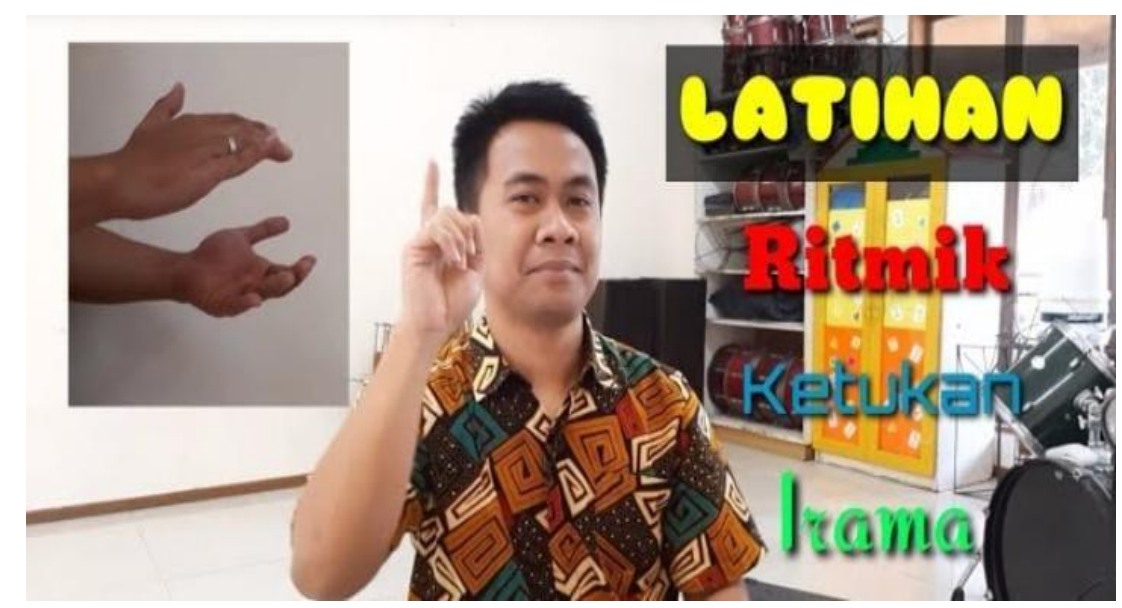

Fig. 1. Learning video displayed by the presenter.

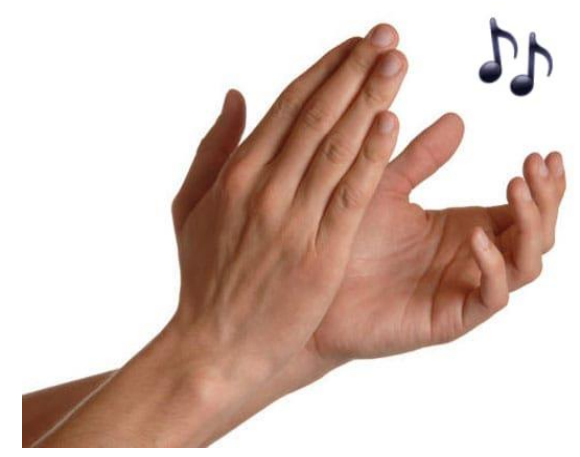

Fig. 2. Learning illustration

Based on the results of the survey and material posted on Table 1, it obtained data that students were serious in exploring the material that had been given. The students' knowledge of tempo and rhythmic during the pretest was $49.7 \%$, but after being briefed on learning theory, the percentage of students' knowledge experienced a drastic increase of $81.2 \%$. Then it can be concluded that most students have understood and mastered the given theory.

The results show several discussion points:

i. For question number one the results increased by $20 \%$ after the material of rhythmic has been given.

ii. For question number two the results increased quite significantly by $33.7 \%$, students quite understand about the rhythmic.

iii. For question number three the results increased by $33.3 \%$, students understand about tempo. 
iv. For question number four the results increased by $16.6 \%$ after being given material of the kinds of tempo.

v. For question number five the results increased by $33.3 \%$ when after being given the material of musical instruments.

vi. For question number six the results are quite increased by $16.7 \%$ after being practiced.

vii. For question number seven the results increased $20 \%$. The students were curious about tempo.

viii. For question number eight the result increased $43.3 \%$ after being given the material about the differences between tempo and rhythmic.

ix. For question number Nine there was increased significantly by $60 \%$. Students were satisfied in learning the material of rhythmic.

x. For question number ten was increased by $33.3 \%$. all is good.

Table 1. Pre-test and post-test.

\begin{tabular}{|c|c|c|c|c|}
\hline No & Question & Pre-test & Post-test & Gain \\
\hline 1. & $\begin{array}{l}\text { Have you understood about rhythmic } \\
\text { before? }\end{array}$ & $60.3 \%$ & $83.3 \%$ & $20 \%$ \\
\hline 2. & How far do you understand about rhythmic? & $50 \%$ & $83.7 \%$ & $33.7 \%$ \\
\hline 3. & Do you know what tempo is? & $50 \%$ & $83.3 \%$ & $33.3 \%$ \\
\hline 4. & Can you name the kinds of tempo? & $66.7 \%$ & $83.3 \%$ & $16.6 \%$ \\
\hline 5. & $\begin{array}{l}\text { Do you know about the kinds of rhythmic } \\
\text { musical instruments? }\end{array}$ & $50 \%$ & $83.3 \%$ & $33.3 \%$ \\
\hline 6. & Have you been able to practice tempos? & $50 \%$ & $66.7 \%$ & $16.7 \%$ \\
\hline 7. & How far do you understand about tempo? & $60 \%$ & $80 \%$ & $20 \%$ \\
\hline 8. & $\begin{array}{l}\text { Do you know the difference between } \\
\text { tempo and rhythmic? }\end{array}$ & $40 \%$ & $83.3 \%$ & $43.3 \%$ \\
\hline 9. & $\begin{array}{l}\text { How satisfied are you in learning the } \\
\text { material about rhythmic? }\end{array}$ & $20 \%$ & $80 \%$ & $60 \%$ \\
\hline 10 & $\begin{array}{l}\text { How satisfied are you in learning the } \\
\text { material about tempo? }\end{array}$ & $50 \%$ & $83.3 \%$ & $33.3 \%$ \\
\hline & Total & $49.7 \%$ & $81.2 \%$ & $31.2 \%$ \\
\hline
\end{tabular}

\section{Conclusion}

Based on the results of research on the development of rhythmic teaching materials for junior high school students, it can be concluded that teachers can understand the essence of rhythmic learning to students by using teaching materials through online learning media as a reference for supporting the preparation of rhythmic teaching materials. From the data obtained from the Google Form results, it shows that as many as $31.5 \%$ of students can process 
the tempo well, and it can also be seen how far the level of students' understanding of the material that has been taught, we can find some of the students' abilities in processing tempo through rhythmic so that it can be practiced in doing musical instrument.

\section{Acknowledgement}

We acknowledged Bangdos, Universitas Pendidikan Indonesia. We thank to Mrs. Ria Lestari, M.Pd from Junior Highschool 12 Bandung. This study is a part of community service (Program: Community Service Program Tematik Literasi 202126 August 2021 - 26 September Group 20. Institute for Research and Community Service (LPPM), Universitas Pendidikan Indonesia. We also thank to Kantor Jurnal dan Publikasi, Directorate of International Affairs, Universitas Pendidikan Indonesia. We thank to Nissa Nur Azizah, Dwi Fitria Al Hussaeni, Dr.Eng. Asep Bayu Dani Nandiyanto, S.T., M.Eng., Muktiarni, S.Pd., M.Pd, and Asri Wibawa Sakti, M.Pd.

\section{References}

Audina, D. S. M. \& Kosasih, E. 2018. Pengembangan bahan ajar (handout) ritmis untuk siswa kelas 1 sekolah dasar. PEDADIDAKTIKA: Jurnal Ilmiah Pendidikan Guru Sekolah Dasar, 5(3), 276-286.

Fajra, M., Jalinus, N., Jama, J., and Dakhi, O. 2020. Model pengembangan kurikulum sekolah inklusi berdasarkan kebutuhan perseorangan anak didik. Jurnal Pendidikan, 21(1), 51-63.

Fajra, M., Ambiyar, A., Rizal, F. \& Dakhi, O. 2020. Pengembangan model evaluasi kualitas output pembelajaran teknik komputer dan jaringan di SMK kota Padang. Cakrawala: Jurnal Pendidikan, 14(1), 1-9.

Ferdiyansyah, F., Ambiyar, A., Zagoto, M. M. \& Putra, I. E. D. 2020. Pemanfaatan media pembelajaran berbasis e-learning dalam meningkatkan hasil belajar pada matakuliah media pembelajaran musik. Komposisi: Jurnal Pendidikan Bahasa, Sastra, dan Seni, 21(1), 62-72. http://ejournal.unp.ac.id/index.php/komposisi/article/view/108082

Hastini, L. Y., Fahmi, R., and Lukito, H. (2020). Apakah pembelajaran menggunakan teknologi dapat meningkatkan literasi manusia pada generasi $\mathrm{Z}$ di Indonesia ?. Jurnal Manajemen Informatika (JAMIKA), 10(1), 12-28.

Hidayatullah, R. 2020. Konvergensi Paradigma Pendidikan Musik. Prosiding Seminar Internasional Pendidikan Seni Tari dan Musik. Universitas Negeri Malang, 9 September 2020, 149-167.

Nurita, T. 2018. Pengembangan media pembelajaran untuk meningkatkan hasil belajar siswa. Jurnal Masyarakat, 3(1), 171-187. 
Shukla, T., Dosaya, D., Nirban, V. S. \& Vavilala, M. P. 2020. Factors extraction of effective teaching learning in online and conventional classrooms. International Journal of Information and Education Technology, 10(6), 422-427.

Syafi'i, A., Marfiyanto, T. \& Rodiyah, S. K. 2018. Studi tentang prestasi belajar siswa dalam berbagai aspek dan faktor yang mempengaruhi. Jurnal Komunikasi Pendidikan, 2(2), 115123.

Zhafira, N. H., Ertika, Y. \& Chairiyaton. 2020. Persepsi mahasiswa terhadap perkuliahan daring sebagai sarana pembelajaran selama masa karantina covid-19. Jurnal Bisnis Dan Kajian Strategi Manajemen, 4(1), 37-45. 